\title{
Talents in the Service of Justice: : Responding to Unequal Ownership beyond Compliance
}

\section{Päivänsalo, Ville Juha}

2016-05

Päivänsalo , V J 2016 , ' Talents in the Service of Justice: Responding to Unequal

Ownership beyond Compliance ' , De Ethica , vol. 3 , no. 1 , pp. 59-74 . https://doi.org/10.3384/de-ethica.2001-8819

http://hdl.handle.net/10138/164426

https://doi.org/10.3384/de-ethica.2001-8819.163159

cc_by_nc

publishedVersion

Downloaded from Helda, University of Helsinki institutional repository.

This is an electronic reprint of the original article.

This reprint may differ from the original in pagination and typographic detail.

Please cite the original version. 


\title{
Talents in the Service of Justice: Responding to Unequal Ownership beyond Compliance
}

\author{
Ville Päivänsalo
}

\begin{abstract}
Over the past few decades, economic inequalities have continued to grow in most countries and the world is still lacking effective global tax schemes or corresponding structures of global distributive justice. Thus, for the world's top-owners, simply complying with the existing rules hardly suffices as a virtue of justice. In the current article, G. A. Cohen's nation-centered account of individual virtues in the service of distributive justice is elaborated further in a broader perspective. First, Cohen's basic insights into the virtues of the talented rich are reconsidered under the conditions of highly unequal Western democracies in the global age as recently depicted by Thomas Piketty. Second, it is asked with reference to the Bill and Melinda Gates Foundation, if the exceptional generosity of some superrich people can serve as a proper response to the assumed deficit of justice. Third, an ethic of generous compliance is outlined as a possible mediating approach in the discussion of the responsibilities of the talented rich in an age of high economic, health, and capability inequalities as well as public sector austerity.
\end{abstract}

\section{Introduction}

Economic inequality has reached long-term heights in most countries across the globe. The distribution of wealth has indeed accumulated in the narrow top: the richest centile of people owns about half of the global wealth today. ${ }^{1}$ Simultaneously, virtually all states even in the global North are struggling under heavy debt burdens and thereby are at risk of losing their positions as the primary responsible agents of justice. ${ }^{2}$ In this situation it is

\footnotetext{
1 Thomas Piketty, Capital in the 21st Century (Cambridge, MA: Belknap Press of Harvard University Press, 2014), pp. 438. Oxfam, Even It Up: Time to End Extreme Inequality (2014), p. 8 (Available online at https://www.oxfam.org/sites/www.oxfam.org/files/file_attachments/cr-even-it-up-extremeinequality-291014-en.pdf (accessed 2016-02-28)), in turn, calculated that at the start of 2014 'the richest 85 people on the planet owned as much as the poorest half of humanity' and reported that the rich have continued to grow richer.

2 About the idea of primary, secondary, and perhaps also tertiary responsible agents of justice, see Ivar Kolstad, 'Human Rights and Assigned Duties: Implications for Corporations', Human Rights
} 
a necessity of justice to reconsider the responsibilities of the affluent class to promote human development. What kind of virtues among the wealthy and the capable could legitimately strengthen and complement states as the primary responsible agents for social rights-or might justice be sufficed if some of the superrich donated very generously to adequate social purposes?

In Rescuing Justice and Equality (2008), Oxford philosopher G. A. Cohen presented one of the most elaborated philosophical attempts to integrate individual responsibilities into the discussion of reasonably egalitarian social justice. He importantly clarified the logics of voluntary compliance of the talented affluent in support of justice. ${ }^{3}$ Whereas Cohen assumed mainly the context of Western liberal democracies, Kevin W. Grey has started to elaborate a global Cohenian approach. ${ }^{4}$ Also, for example, the representatives of the human capabilities approach to development, centrally including Amartya Sen and Martha Nussbaum, have made interesting openings about responsibilities for development across the globe. ${ }^{5}$ Onora O'Neill, Thomas Pogge, and Peter Singer are among those who have also put the discussion forward. ${ }^{6} \mathrm{~A}$ lot, however, is still open about human capabilities or talents when it comes to the responsibilities for global justice. In particular, if we have no stable structures of global distributive justice in place, should we then merely flag for philanthropy?

In the present paper, the talents of the wealthy are conceptualized as a possible resource for just development under the conditions of public sector austerity beyond a national scope. I will particularly argue for the reasonable responsibility of the affluent class to support democratic states as the primary responsible agents of just development. I call my own approach an emerging ethic of generous compliance. This approach allows for a reasonable growth of inequalities e.g. through liberty and merits. However, the basic problem with the current inequalities - of wealth and also of some capabilities - is that they are too

Review 10:4 (2009), pp. 569-582; about the need of the viable third sector especially when indebted states have difficulties in implementing social rights as intended, see Niall Ferguson, The Great Degeneration: How Institutions Decay and Economies Die (London: Penguin Books, 2012). From 2008 to 2015, the total debt for OECD countries rose from nearly 80 percent of gross domestic product (GDP) to around 111 percent (Valentine Pasquali, 'Percentage of Public Debt in GDP Around the World', Global Finance 31 October (2015), p. 1. Available online at https:/ / www.gfmag.com/globaldata/economic-data/ public-debt-percentage-gdp?page=2 (accessed 2016-02-28)).

${ }^{3}$ G. A. Cohen, Rescuing Justice and Equality (Cambridge: Cambridge University Press, 2008).

${ }^{4}$ Kevin W. Gray, 'The Scope of the Global Institutional Order: Can Pogge Survive Cohen's Critique of Rawls?', De Ethica 2:2 (2015), pp. 23-38.

${ }^{5}$ Nussbaum's main concern has been to secure a threshold of central human capabilities around the globe but not really the realization of distributive justice, see e.g. Martha Nussbaum, Creating Capabilities: The Human Development Approach (Cambridge, MA: Belknap Press of Harvard University Press, 2011). Sen has discussed responsibilities of justice flexibly across the division of the public and the private sphere and across regions, but not with such a systematic focus on the responsibilities of the talented wealthy as Cohen has done. See e.g. Amartya Sen, The Idea of Justice (Cambridge, MA: Belknap Press of Harvard University Press, 2009). About individual responsibilities for global poverty, see also Abigail Gosselin, 'Global Poverty and Responsibility: Identifying Duty-Bearers of Human Rights', Human Rights Review 8:1 (2006), pp. 35-52.

6 Onora O'Neill, Bounds of Justice (Cambridge: Cambridge University Press, 2000); Thomas Pogge, World Poverty and Human Rights: Cosmopolitan Reforms and Responsibilities (Cambridge: Polity, 2002); Peter Singer, The Most Good You Can Do: How Effective Altruism Is Changing Ideas about Living Ethically (New Haven, CT: Yale University Press, 2015). 
huge to be explained sufficiently through such legitimizing notions. And although much of the present inequalities can be explained though outright criminal activities (which would be another story), the question of the responsibilities of the top-owners is bound to be of extreme importance in the endeavors of global distributive justice.

An ethic of generous compliance encourages philanthropy, especially when democratic states are unable to manage their responsibilities on their own. This defense of philanthropy does not stem from Utilitarian or particularly altruistic premises. Whereas e.g. Peter Singer's idea of effective altruism is rooted in Utilitarianism and recommends us to do 'the most good we can',7 I am mainly taking part in the discussion on fair baseline justice. I hereby assume, like John Rawls, that usually it is not a matter of justice to request people to do as much good as they can but rather to comply with fairly designed institutions. Beyond Rawls, however, I call attention to circumstances in which the prevailing institutions are far from fair and defend generousness under such nonideal conditions-especially in the case of the talented rich. My position thus is in this respect closer to that of Rawls than Singer when it comes to its starting point, albeit at the practical level the generousness it promotes may resemble effective altruism as put forward by Singer.

In many cases generousness can be a matter of justice for the following reason which Pogge has underlined: those who have benefited from unfair global structures have the duty of justice to compensate for this. ${ }^{8}$ In particular, the talented rich might adopt this kind of duty until the relevant institutions have essentially become fairer. But this article, as said, is mainly about Cohen's view, which explicitly addresses the case of the talented rich as a matter of justice. I will thereby defend (1) Cohen's basic assumption that capable people must internalize the idea of social justice and thus contribute to the maintenance of a reasonably egalitarian society and (2) my own approach of generous compliance that supports both tax compliance and philanthropy as important aspects of such an internalized idea of justice in times of public sector austerity.

I will refer to the Bill and Melinda Gates Foundation as an example of a response among the superrich to the call for generosity. But to reiterate, I will argue that grandscale philanthropy is best conceived as a virtue of justice only as a temporary or suitably limited project, for it lacks the kind of democratic accountability characteristic of democratic states. The approach of generous compliance thus urges the talented rich to voluntarily comply with effective reforms for a more egalitarian state-centered global distributive justice. Moreover, when the role of philanthropy eventually diminishes, then also the challenge of implementing basic social rights, such as the entitlements of central human capabilities in a democratically accountable manner, could become easier.

The case of Bill Gates is intriguing here for instance because, as Piketty has pointed out, he belongs to those superrich who have, to a significant degree, deserved to be affluent. In addition, the Gates Foundation is an illuminating case from the perspective of Amartya Sen's insistence that any approach to distributive justice that

7 Singer, The Most Good You Can Do, p. 1. As Singer repeatedly says, the lifestyles of effective altruists do not tend to be particularly burdensome. In this sense - not being extremely demanding - Singer's approach appears to be reasonable.

8 Pogge, World Poverty and Human Rights, pp. 12-13. I would add here that even if the current global structures benefited the poor in some respects, the unfairness of these structures can nevertheless be clear enough to legitimize the Poggean argument for the negative duty of the globally affluent to help the globally poor. 
merely looks at economic measures is peculiarly narrow. Gates's contributions have clearly brought about a lot of progress, for example in terms of health-related capabilities. But the impressive results of the Gates Foundation do not refute the aforementioned suggestion that private foundations, being free from direct democratic accountability, do not suit the role of primary responsible agencies of democratic social justice as properly as democratic states themselves.

\section{Talents and Inequality in a Free Society}

The natural lottery, to use Rawls's term from A Theory of Justice (1971), endows people with various types and levels of endowments. It is also usual in a free society that the better endowed end up with better social positions over their course of life, becoming wealthier, healthier, and more capable than the less talented. Rawls thought that this is basically satisfactory insofar as the efforts of the more talented also benefit the least advantaged in terms of so-called primary goods. ${ }^{9}$ At the level of its starting points, Rawls's theory is highly egalitarian-it even appears to include a kind of common ownership of capabilities. ${ }^{10}$ But when applied to practice, could the Rawlsian approach nevertheless provide too much to the naturally talented? This is what Cohen has indeed suggested.

The narrowly structural focus of Rawls's account is at the heart of Cohen's criticism. Does Rawls's theory disregard the virtues of individuals and thereby allow any self-interested talented person to utilize the markets quite blatantly? Cohen remarks that Rawls did assign duties to individuals in terms of so called natural duties. But this is not really relevant, Cohen continues, in Rawls's account of distributive justice, which centrally relies on the idea of the moral division of labor between the state and a lawabiding citizen. It is precisely this division that allows Rawls to defend both the freedom of a citizen to do as he pleases in the domain of distributive justice and a substantial account of distributive justice. ${ }^{11}$ Cohen thus interprets Rawls to essentially say that (1) 'distributive justice is a task for the state alone' (italics mine) and to deny that (2) also an individual must show some regard to distributive justice and (3) both the state and the individual must clearly show this regard (Cohen's own view)..$^{12}$ My view accords basically with (2), though I would reiterate that the amount of such a regard could vary greatly depending on the successfulness of the state in the field of distributive justice.

Cohen does not seem to take into account Rawls's concept of reasonableness in full, 13 but be this as it may, let us now focus on Cohen's own position. Cohen illuminates

\footnotetext{
9 John Rawls, A Theory of Justice (Cambridge, MA: Belknap Press of Harvard University Press, 1971), pp. 65-83.

10 Rawls pointed out that the principle of equal liberty and the difference principle (which supports maximizing the position of the least advantaged in a society) are equivalent to an undertaking to regard the distribution of natural abilities as a collective asset so that the more fortunate are to benefit only in ways that help those who have lost out' (A Theory of Justice, p. 179).

11 Cohen, Rescuing Justice and Equality, pp. 8-9.

12 Ibid., p. 10.

${ }^{13}$ In its various development stages, Rawls's theory always included the idea of reasonable persons as basically ethical persons, not as self-interested users of the system. See e.g. Ville Päivänsalo,
} 
his assumption about individuals' responsibilities for distributive justice through a hypothetical example of a talented medical doctor who could benefit many people simply by exercising her profession. She is, however, fond of gardening, from which she could earn $£ 20,000$ a year. She would actually prefer gardening to doctoring unless she were paid $£ 50,000$ a year for doctoring. Now the problem for those who want to defend equality, freedom, and the benefits of the talented doctor's services basically takes the form of the following trilemma. If the benefits of service and the freedom (of occupation) of the doctor-gardener are to be rescued, then she must be paid $£ 50,000$ - and equality is gone. If the benefits of service and equality are rescued, then this doctor-gardener must be compelled to work-and freedom is lost. Finally, if both freedom and equality are rescued, then we miss out on the benefits of her skillful service. ${ }^{14}$ When in need of the services of talented doctors, society may thus need to provide them with high economic incentives to serve the people and to allow inequalities to grow. Cohen emphasizes that these kinds of developments have indeed occurred in for instance the United Kingdom and the United States. ${ }^{15}$

Cohen himself ultimately resolves the trilemma by assuming that an ethical doctoral-gardener is freely willing to serve society to a degree. ${ }^{16} \mathrm{I}$ basically endorse this solution, integrating it into my own view in the following form: freely internalized responsibility for distributive justice is needed to complement the state-centered approach to distributive justice. This responsibility or virtue then needs to be substantial enough so that it enables the implementation of the kinds of equality, freedom, and social services that are constitutive of a just democratic society.

This Cohenian approach allows some degree of inequality to emerge merely as a matter of liberty-it requests the talented neither to accept complete equality nor to simply maximize social benefits. Also when Cohen reconstructs Rawls's main argument about distributive justice, he takes it for granted that the talented have better opportunities than the untalented to achieve income and wealth as well as other social goods. ${ }^{17}$ In any Cohenian approach, however, the talented are to use their liberty in a way that takes into account the demands of equality and desert (or merit). ${ }^{18}$

\section{Taking Desert into Account}

Whereas some talented individuals become affluent simply through the free market, others may legitimately deserve to be paid well. Cohen is in this respect critical of the

Balancing Reasonable Justice: John Rawls and Crucial Steps Beyond (Aldershot, UK: Ashgate, 2007) pp. 36-37, 84-85, 128-140.

14 Cohen, Rescuing Justice and Equality, pp. 184-186.

15 Cohen's focus is on the tax cut introduced by Chancellor Nigel Lawson in the UK in 1988, namely, dropping the top tax from 60 to 40 percent. This was publicly legitimized through the alleged intention to make the worst off people materially better off.

16 Cohen, Rescuing Justice and Equality, p. 215.

17 Ibid., pp. 96-97.

18 I use 'desert' and 'merit' interchangeably in this article. Broadly speaking, these concepts refer both to the idea that a person has deserved or earned his or her affluence and to the idea that it brings about further merit if a person's effort benefits the society - I have tried to express clearly enough in each case, which type of desert or merit I am focusing on. 
Rawlsian approach, which would assign the talented further benefits because their labor is also supposed to improve the position of the less fortunate. Cohen challenges precisely these further benefits: why should society favor those who are in any case likely to succeed better than others? ${ }^{19}$ In cases where the labor of the talented is particularly toilsome, though, then Cohen maintains that the talented can be entitled to further benefits for their socially useful efforts. ${ }^{20}$

Like Cohen, Robin Hahnel has also argued that talents as such are not something that should automatically be rewarded. Hahnel assumes first, suggesting that this is a relevant simplification in the context of distributive justice, that the social value of a labor contribution is a combination of talent and effort. He then compares the merits of a brain surgeon, who operates at a high level of both talent and effort, to those of a garbage collector, whose talents are at a basic level but whose efforts are equal to those of the brain surgeon. Hahnel points out that here effort really is the only factor that both these persons have control over. Focusing on it would strictly speaking equalize the rewards in question. Seen more broadly, 'effort' could mean for instance longer working hours, unhealthier or more dangerous working conditions, or less pleasant work or a less gratifying education. ${ }^{21}$ It is difficult to say just how radical his account of economic justice eventually is, but at least it clarifies the radically egalitarian potential in any approach that questions an individual's entitlement to merits based on his or her talents.

Neither Cohen nor I represent that radical egalitarianism. Recall that in a free society, as pointed out above, at least some degree of economic differences can legitimately emerge when the services of the talented are valued higher than those of the less talented. But Cohen's position can be said to accord with that of Hahnen here: Cohen rejects any extra compensation for the talented while accepting an extra compensation on the basis of extra effort. My position, in turn, is more Rawlsian in this issue. Even though person $\mathrm{X}$ has not deserved his or her talents to begin with, person $Y$ has not deserved, prima facie, the entitlement to the benefits from $X$ 's talents either. Thus we can legitimately and fairly agree, as a matter of social contract, that those who use their talents to benefit others will be rewarded. ${ }^{22}$ Only a peculiarly strong notion of the collective ownership of talents could refute such a position. In my view, hence, although we have not originally deserved out talents, we can deserve compensation if we have used our talents in a socially beneficial way. Sometimes this takes a lot of effort and sometimes less-further compensation for a particularly burdensome personal effort involved would usually be adequate. If, in turn, our talents have developed largely due to the efforts of others, such as our parents and teachers, we will need to share with them the merit resulting from socially beneficial labor.

In the so-called standard case, Cohen depicts the work of the talented as actually 'more congenial' than that of others. ${ }^{23}$ Thus, the talented could not usually argue for extra

${ }_{19}$ Cohen, Rescuing Justice and Equality, p. 97.

20 Ibid., pp. 98-107.

21 Robin Hahnel, Economic Justice and Democracy: From Competition to Cooperation (New York: Routledge, 2005), pp. 26-31. Subsequently he also takes into account responding to human needs as a relevant criterion of justice.

22 As Rawls puts it, '[t]he naturally advantaged are not to gain merely because they are more gifted, but only to cover the costs of training and education and for using their endowments in ways which help the less fortunate as well.' (A Theory of Justice, pp. 101-102)

${ }^{23}$ Cohen, Rescuing Justice and Equality, p. 103. 
rewards on the basis of the burdensomeness of their jobs. Yet we must ask if Cohen's very general empirical assumption is really warranted. People in both leading and lowwaged positions can be highly stressful. Whereas Bill Gates once warned an applicant that the responsibility of being a chief executive officer (CEO) can be 'more burdensome than he had expected' and even 'an inhuman job', ${ }^{24}$ clearly many badly paid jobs are also demanding in something like inhuman ways. In an ethic of generous compliance there is no need for overarching empirical generalizations about the burdensomeness of jobs. Such issues could be considered case-by-case when needed.

I do not seek any grand generalizations on the burdensomeness of virtue either. The efficient altruists that Singer depicts tend to be highly talented, in leading positions, and donating generously-and are happy as well. ${ }^{25}$ In my approach, in turn, it brings about merit if one is involved in a socially beneficial labor that is evidently burdensome. It is even better if people manage to be happy despite assuming challenging altruistic responsibilities, but I do not regard such a mentality-or the gift of happiness-as a baseline assumption in an ethics of generous compliance.

To sum up, beyond the original freedom of the talented to reasonably benefit from their talents, should they be entitled, as a matter of justice, to any extra compensation for their socially beneficial efforts? Unlike Cohen, I would answer affirmatively here when there are evident social benefits particularly to the least advantaged. Yet the talented, guided by their internalized sense of reasonably egalitarian justice, would not expect any splendid compensations or rewards. Accordingly, it would seem adequate and fair to give the talented some extra benefits because of their useful service beyond what they might have already earned in a free and reasonably egalitarian society.

In addition, as recognized in Cohen's account as well as in mine, particular diligence in one's good work or involvement in evidently burdensome tasks could add the merit to be taken into account in the considerations of distributive justice. But again, rewards that are conductive to huge socio-economic inequalities, ones that appear as unreasonable to almost anyone who seriously reflects upon them, can no longer be justified in this manner, not at least within the framework of generous compliance.

\section{Locating Responsibilities among Economic Classes}

In Piketty's groundbreaking treatise on economic history, most figures concerning the distribution of both income and ownership in Western countries since around 1900 follow a rather uniform pattern. The beginning of the twentieth century was a time of marked inequalities, which were subsequently leveled down mainly due to the two World Wars. There followed a period of moderate inequalities lasting up to the 1970s or so. Thereafter, the inequalities of both income and assets have grown again, developing towards extreme patterns, albeit with variation across countries and with different

24 Bill Gates, Impatient Optimist: Bill Gates in His Own Words, edited by Lisa Rogak (Richmond, Australia: Hardie Grant Books, 2012), p. 12.

25 ' $[\mathrm{W}] \mathrm{e}$ should not think of effective altruism as requiring self-sacrifice, in the sense of something necessarily contrary to one's own interests.' (Singer, The Most Good You Can Do, p. 4) 
measures. ${ }^{26}$ In the United Kingdom, the overall income inequalities have even reduced a bit since 2007. In the United States, on the other hand, the share of income going to the top one percent has continued to rise. ${ }^{27}$

When it comes to ownership in particular, a cluster of intriguing questions concerns the amount of public wealth and its ratio to private wealth. In Germany, public wealth has always exceeded public debt, from 1870 all the way through to 2010. But in 2010 their amount was almost the same, thereby indicating that the '[n]et public wealth was almost exactly zero' ${ }^{28}$ In Britain and France, the amount of public capital (or wealth) was similarly almost nothing in 2010 according to Piketty. From the 1970s onwards, however, private capital has accumulated rather rapidly in all of these three countries, between 1990 and 2010 most rapidly in France. ${ }^{29}$ In the United States, public wealth continued to exceed public debt significantly in 2010-despite the rising level of the public debt since about 1970. Yet in the big picture, akin to the aforementioned European countries, almost all the national capital of the United States consists of private capital. ${ }^{30}$

Piketty provides some useful terminology to define inequality in private capital ownership. ${ }^{31}$ Allowing the concept of low inequality to remain hypothetical, he depicts the Scandinavian countries from the 1970 s to the 1980 s as examples of medium inequality: there the top one percent (dominant class) owned about 20 percent of the capital, the top 10 percent (upper class) owned 50 percent, and the bottom 50 percent (lower class) owned 10 percent of wealth.

The corresponding inequalities in countries of medium-high inequality, representing most European countries in 2010, are somewhat steeper. In societies of high inequality ( $\approx$ the United States in 2012), in turn, the dominant class owns some 35 percent of wealth, the upper class some 70 percent, and the lower class five percent. Finally, European societies in 1910 were even more unequal, i.e., societies of very high inequality.

Which agencies, then, should be identified as the primary responsible agencies for social rights under conditions of, say, medium-high inequality? Perhaps-as the traditional Nordic intuitions would suggest-public sector agencies? The amount of public wealth in all of the above-mentioned countries, however, was very low in 2010, and public sector austerity has become a commonplace almost throughout Europe thereafter. Even if we thus argue on the basis of ideal principles for the strong public

26 See e.g. income inequalities in the United States, Britain, Canada, and Australia (Piketty, Capital in the 21st Century, p. 316). Also the overall amount of national capital follows a similar pattern for instance in Germany, France, and Britain (p. 147).

27 Atkinson, Inequality: What Can Be Done? (Cambridge, MA: Harvard University Press, 2015), pp. 18-19. In the OECD countries on average, the gap between the incomes of the richest and the poorest deciles grew quickly from the mid-1980s to the mid-1990s and has continued to rise moderately since then (Brian Keeley, Income Inequality: The Gap between the Rich and Poor (Paris: OECD Publishing, 2015), p. 11. Available online at http://www.oecd.org/social/incomeinequality-9789264246010-en.htm (accessed 2016-03-1)). In Latin America, inequalities have reduced since around 2000 (Atkinson, Inequality, p. 79).

28 Piketty, Capital in the 21st Century, p. 143.

${ }^{29}$ Ibid., p. 145. Atkinson's (Inequality, p. 173) representation of the actual public sector net worth (assets minus liabilities) in the UK reveals a major decline around 1990 and another since 2007, and by 2013 this figure was about minus 20 percent of the GPD.

30 Piketty, Capital in the 21st Century, p. 154.

31 Ibid., p. 248. 
responsibility model, its sustainable implementation could be either impossible or very difficult without major changes in the background conditions.

But what about private owners then? In countries of high inequality, the lower class (50 percent of the people) owns merely five percent of wealth. It would indeed sound unreasonable to expect this large group of people to be the prime bearer of responsibility for social rights. They are rather the ones who unavoidably need support from others to manage their affairs. The middle-class (the 40 percent of people above the lower class) will be involved anyway. Yet if distributive justice implies any substantial equalizing policies, prima facie, then the major increase in the overall social responsibility would fall onto the upper class, and particularly onto the dominant class within the upper class. After all, in Piketty's scheme, the upper class (the top 10 percent of people), has command over about 60 percent of wealth in medium-high-income countries and even 70 percent in high-income countries. According to Atkinson's account of personal wealth (including real estate) in the United Kingdom, the top one percent owned some $£ 700$ billion while the remaining 99 percent owned about $£ 2,400.32$

While the generous compliance model provides several possible reasons to legitimize some inequalities, the steepness of inequalities is of quintessential significance. Under the conditions of high economic inequality, it accordingly locates a substantial part of social responsibilities to private owners in the upper and dominant classes. But what kind of responsibilities should people of this class assume? For one thing, many of the better off have deserved good economic positions, and are thus entitled to them. And for another, does it not suffice for the rich to comply with the tax schemes that are democratically imposed upon them?

\section{Supermanagers and Inheritors}

In order to test our intuitions, let us consider a couple of real-life cases. One of the intriguing groups of people highlighted by Piketty are the 'supermanagers' in the English-speaking world. They have been the core group among the top earners in these countries particularly since 1980 . These highly talented people have been able to utilize the opportunities of the technological development splendidly: their earnings from labor have often surpassed the capital gains from inherited wealth. ${ }^{33}$ On the very top, however, the difference disappears. Bill Gates, who first earned his fortune due to his great talent and a great deal of effort, has later on continued to increase his fortune mainly through capital gains at a roughly similar rate as Lilliane Bettencourt, the heiress of L'Oréal

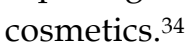

A part of the vast fortunes of Gates, the richest man in the world, could even be justified under the Cohenian egalitarian approach. If we assume that Gates has not requested any extra compensation for his work beyond his earnings in software development, he has had the freedom to benefit from his talent. In Cohen's egalitarian view, however, he should also have expressed a willingness to comply with a somewhat egalitarian tax system. In fact, he has instead expressed satisfaction with the United States

\footnotetext{
32 Atkinson, Inequality, p. 156.

33 Piketty, Capital in the 21st Century, pp. 315-316.

34 Ibid., p. 440.
} 
system as it has been. ${ }^{35}$ Hypothetically spirited by Cohenian virtues, Gates and the other billionaires on the Forbes Magazine's top-owners list could have enabled the United States to collect from them much more taxes than what it has done. Although there are many aspects to Gates's position here, he has in fact affirmed directly to Piketty: 'I don't want to pay more tax.' 36

At least in the eyes of Gates's competitors such as Mitch Kapor, the billionaire cofounder of Lotus Software, Gates has also applied an unfair monopoly strategy in scaling up the success of Microsoft. ${ }^{37}$ As a business leader, Gates has hardly been an altruist towards either state or his competitors. Whether he has created his success by unfair means would require further study, but at least we can safely say that a good part of his wealth cannot be justified in any Cohenian terms.

In an ethic of generous compliance, on the other hand, social merits count as one legitimizing reason for obtaining a position in the upper or dominant class. It is, of course, extremely difficult to assess the 'real social value' of Gates's effort, but it makes sense to assume that it has been great. The software initiated by his effort has clearly brought about progress. Part of the merit, however, also goes to the society that made Gates's success possible. To paraphrase President Barack Obama about the progress in high tech fields more generally: the rule of law, great teachers, roads and bridges, and the originally government-created Internet have all helped the successful to create their businesses. ${ }^{38}$ Hence, it is quite reasonable to expect the winners in this field to pay back substantially to others, at least within their home countries. And to a degree, referring e.g. to the government's education and justice system, Gates has agreed. ${ }^{39}$ On these grounds, 'supermanagers' share the kind of moral ownership of their fortunes with society. Sincere recognition of this condition could function for them as an important reason to comply with rather extensive tax schemes.

Inheritors, in turn, have characteristically done much less, if anything, to gain their fortunes. Given that e.g. Lilliane Bettencourt's fortune has grown from $\$ 2$ billion in 1990 to $\$ 25$ billion in 2010, she has hugely benefited from the existing system without any (correspondingly) substantial individual or social merit, not at least as indicated by Piketty. ${ }^{40}$ Thereby the ethical framework as developed so far would not grant her any particular reason to oppose taxing her riches quite robustly. Likewise, although Bill Gates originally became rich largely through his own efforts, after recognizing how much the existing system has supported him on his way towards his splendid success, he might well express a degree of Cohenian willingness to comply with some quite substantial tax reforms, both domestic and international.

But before moving on to a philanthropic type of social responsibility, let me here summarize the key insights in the emerging ethics of generous compliance so far.

\footnotetext{
35 In the United States, says Gates (Impatient Optimist, p. 101), thinking about the rise of Microsoft, '[y] ou could build a company with great success without involvement in political activities of any kind.'

36 Quoted in Linsey McGoey, No Such Thing as a Free Gift: The Gates Foundation and the Price of Philanthropy (London: Verso, 2015), p. 24. McGoey does recognize Gates's support for the global tax on currency speculation (p. 22).

37 Ibid., p. 9.

38 See the quote in Ferguson, The Great Degeneration, p. 151.

${ }^{39}$ Gates, Impatient Optimist, p. 120.

40 Piketty, Capital in the 21st Century, p. 440.
} 


\section{Essentials in an Ethic of Generous Compliance}

After the preliminary assumption that criminal or clearly unfair ways of acquiring fortunes are illegitimate anyway, I have called attention particularly to the following insights:

(1) More than mere compliance to the existing global rules must be requested by the rich and the talented as a matter of justice assuming that the existing rules allow too much inequality to be soundly justified as rules of justice;

(2) Particularly in times of public sector austerity, the upper and the dominant class private owners are to willingly comply with such tax reforms that would allow democratic states to function as primary responsible agents in the implementation of social rights;

(3) Those among the rich who have not deserved their increased fortunes through socially beneficial means could be expected to contribute more than those rich whose efforts have clearly benefited society;

(4) In delineating a fair tax scheme, it should be taken into account that many effortbased wealthy people including 'supermanagers' have typically benefited from society during their careers and are thus not the sole creators of their private wealth;

(5) Before reasonably just taxing schemes are in place and in democratic control, which could take a very long time in many contexts, there also is a need for philanthropy funded by the upper class in addition to the less resourceful classes.

Insight (4) above actually implies that it is reasonable to expect the dominant class to comply with proper taxes to be collected to secure social rights at least in their own societies. But given the global nature of the current economic system, which has benefited the dominant class a great deal, the desired kind of willingness to comply must also be clearly extended to global-level reforms.

\section{Including Health: Primarily through Democracy}

As Amartya Sen and other representatives of the so-called capabilities approach to human development have emphasized time and again, theorists of social justice need conceptual frameworks that are flexibly sensitive to a number of measures of human development beyond income and wealth. One of the most broadly used is good health, a recognizably salient human good, for example, in the views of Pogge and Singer as well as of Norman Daniels, Jonathan Wolff, Jeffrey Sachs, and almost any major author on global justice. Focusing now on the affluent class as saliently responsible for global health and health-related capabilities, it is worth pointing out that hardly any individual has done more in this respect than Bill Gates. 
Gates has transformed billions of dollars into health among the lower class people worldwide through the Bill and Melinda Gates Foundation. From 1994 to 2006, Bill and Melinda Gates donated more than $\$ 26$ billion to their foundation ${ }^{41}$ and altogether more than US $\$ 30$ billion. ${ }^{22}$ Beyond doubt, through dozens of development programs, these donations have brought about huge social benefits across the globe. Hence, this appears to be a very promising real-life case of generous compliance.

It is also worth comparing, however, the above-mentioned donations to Bill Gates's fortune as a whole, which has been reported to have grown from $\$ 4$ billion in 1990 to $\$ 50$ billion in $2010^{43}$ and even to $\$ 78.5$ billion by November $2015 .{ }^{44}$ Concerning annual donations, in 2015 Bill Gates headed the list of philanthropists in the United States with a sum of $\$ 1.9$ billion. ${ }^{45}$ If channeled to single countries, this level of financing could cover the expenses of entire social sectors. For example, the United Republic of Tanzania, as of 2010, spent US\$1.4 billion on health care and Rwanda no more than US\$590 million. ${ }^{46}$ By doubling or tripling his donations, Gates alone could easily cover half of the health spending of many poor countries-and still become richer, assuming that his fortune continued to grow at a similar pace as previously. But hypothetical cases aside, the Gates Foundation actually finances about 10 percent of the World Health Organization's budget and, as of 2013, donated to the UN Health Agency more than the United States. ${ }^{47}$

Gates has thereby paid a great deal back to the global society through donations, in addition to taxes. Yet his generous contributions may not suffice to compensate for his unwillingness to comply with such tax reforms that could arguably be fairer than the current system. Certainly, most people in the dominant class do not contribute to social progress even remotely as much as Gates. However, without internalized support by the dominant class the democratic states in Europe, North America, and elsewhere may not be able to establish reasonably fair tax schemes. Hence, it remains inherently problematic whether dominant and upper-class people bear their responsibilities disproportionally through philanthropy.

In addition, if the share of donations and aid grew really substantially in a particular country, this can no longer be the ideal situation from the standpoint of democracy. Grand scale philanthropy risks transforming the entire service system in a

41 The Bill and Melinda Gates Foundation, 'Who We Are' (2015), Foundation FAQ. Available online at http:/ / www.gatesfoundation.org/Who-We-Are/General-Information/Foundation-FAQ (accessed 2015-11-15).

42 Forbes, 'Bill Gates on Forbes Lists \#6: Powerful People (2015)'. Available online at http://www.forbes.com/profile/bill-gates (accessed 2015-11-15). This figure is not directly comparable to the previous one; the sources begin to count the donations from different years onwards.

43 Piketty, Capital in the 21st Century, p. 440.

${ }^{44}$ Real Time Net Worth as of 11/15/15: \$78.5 Billion (Forbes, 'Bill Gates on Forbes Lists \#6').

45 The Chronicle of Philanthropy, 'Special Report February 08, 2015: The 2015 Philanthropy 50', updated 2 March 2015. Available online at https://philanthropy.com/specialreport/the-2015philanthropy-50/3 (accessed 2015-11-15).

46 The World Health Organization (WHO), WHO Global Health Expenditure Atlas (Geneva: The WHO, 2012. Available online at http://apps.who.int/nha/atlasfinal.pdf (accessed 2015-11-15)), pp. 46,55 .

${ }^{47}$ McGoey, No Such Thing as a Free Gift, pp. 8-9. 
non-democratic direction. Certainly, the talented rich are free to do a lot of good. Nevertheless, as McGoey has pointed out about 'philanthrocapitalists', when using their own properties as they like, they do not necessarily have any democratic accountability beyond democratic side constraints. 48

Returning to the case of Tanzania, its health sector has become increasingly dependent on foreign aid. According to a report supported by the Gates Foundation, the share of foreign resources in the country's health sector budget increased 'from 31 percent in 2004/5 to 37 percent of the total expenditures in $2008 / 9^{\prime} .{ }^{49}$ And the WHO figure for 'Funding from abroad' to health care in Tanzania, as of 2010, was as high as 49 percent. ${ }^{50}$ While this figure includes all foreign aid, it is clear that with such a high degree of dependency on aid from abroad the local government could not have a firm democratic control in the field. Part of the problem is the sheer diversity of agencies in the health sector of the country. ${ }^{51}$ Add to this the fact that giving to charities tends to be emotionally based - as Singer has also admitted. ${ }^{52}$

In a reasonably egalitarian welfare democracy, in turn, the internal compliance of the talented would enable states to be strong and wealthy enough to take care of social justice. Hence, there would usually be no need for huge philanthropic initiatives. Admittedly, such ideal societies have historically speaking been rare. Therefore, great philanthropists are also needed, not least nowadays as the public economies of most high-income countries struggle under heavy burdens of debt. But this condition should not make us forget the deficiency of democracy in grand-scale philanthropy. When using the term generous compliance, I am in this spirit referring to the willingness of the talented wealthy to support the possibilities of the states to strengthen their public sectors as well as to become involved in complementary philanthropic activities.

The democratic control of philanthropy includes the idea of a viable civil society discussion. Peter Singer has even called attention to metacharities as salient agencies in this discussion, i.e., altruistic agencies that control other altruistic agencies. ${ }^{53}$ This kind of control may usefully complement what democratic states and the corresponding international agencies can do. But at which point should we then begin to talk about some kind of charitocracy instead of democracy? Or, if the people in the control of largescale charities actually come from the dominant class, is the question essentially about plutocracy (the rule of the wealthy) as a form of oligarchy? Moreover, the fewer affluent altruists involved, the more likely it is that this approach will remain democratic. Yet the presence of a really broad diversity of minor charity agencies runs the risk of a kind of anarchy in this field.

${ }^{48}$ McGoey, No Such Thing as a Free Gift, pp. 8-9.

49 Action for Global Health and German Foundation for World Population (GWP), Health Spending in Tanzania: The Impact of Current Aid Structures and Aid Effectiveness (October 2010), p. 10. Available online at http:/ / www.dsw.org/uploads/tx_aedswpublication/2010_10_PolicyBriefing2_Final1_ LoRes_Tanzania.pdf (accessed 2015-11-15).

50 WHO, WHO Global Health Expenditure Atlas, p. 55.

51 See e.g. the figure on 'key diplomatic spaces for participating in health policy processes' in South Africa, Tanzania, and Zambia (Amy Barnes, Garrett Wallace Brown and Sophia Harman, Global Health Reforms in Africa: Performance, Participation and Policy (Houndmills, UK: Palgrave, 2015), pp. 13-14).

52 Singer, The Most Good You Can Do, p. 149.

53 Ibid., pp. 149-164. 
It is indeed a great challenge to the analysis that philanthropists akin to Gates are not mainly distributing money to the poor but are often investing in initiatives designed to enhance their health and other capabilities. This makes it even more difficult to assess the types of social benefits promoted by the approach and also to evaluate the use of power through these contributions. The Gates Foundation has actually disbursed funds to a broad range of development objectives since its beginning. In Our Big Bet for the Future: 2015 Gates Annual Letter, Bill and Melinda Gates depict the original idea of their agency as follows: 'We started our foundation in 2000 with the idea that by backing innovative work in health and education, we could help dramatically reduce inequity' ${ }^{54}$ This insight is clearly far from the idea of simply giving money to the poor. The approach of the world's richest and perhaps the world's sixth most powerful person ${ }^{55}$ is far more about cultivating capabilities/talents at various levels of expertise in the service of human development.

But much depends on the kind of egalitarian focus in the approach. The philanthropy of upper-class people cannot really be egalitarian in any strict sense. Nevertheless, it can reduce at least some inequalities through helping the poor to defeat illnesses and to achieve a threshold of human capabilities as well as through redistributing financial assets.

\section{Concluding Remark about an Ethic of Generous Compliance}

In an ethic of generous compliance it is assumed that democratic states are still best positioned to serve as the key responsible agents of social justice-and the talented wealthy do well to support them in this role. Although privately funded humanitarian and development initiatives do a lot of good, with their limited accountability they are better suited to the roles of secondary responsible agents of just development. However, before democratic states e.g. in Europe recover from their severe public sector austerity and many other states become properly democratic in the first place, there is also a pressing need for the philanthropy of the talented wealthy in the service of justice.

Ville Päivänsalo, University of Helsinki ville.paivansalo@helsinki.fi

\section{Bibliography}

Action for Global Health and German Foundation for World Population (GWP). Health Spending in Tanzania: The Impact of Current Aid Structures and Aid Effectiveness (October 2010). Online at: http://www.dsw.org/uploads/tx_aedswpublication/2010_10_ PolicyBriefing2_Final1_LoRes_Tanzania.pdf (accessed 2015-11-15).

54 Bill and Melinda Gates, Our Big Bet for the Future: 2015 Gates Annual Letter (Seattle, WA: Bill and Melinda Gates Foundation), p. 1. Available Online at http://www.gatesnotes.com/2015-annualletter\#0 (accessed 2016-03-1).

55 Forbes, 'Bill Gates on Forbes Lists \#6: Powerful People (2015)'. 
Atkinson, Anthony B. Inequality: What Can Be Done? Cambridge, MA: Harvard University Press, 2015.

Barnes, Amy, Garrett Wallace Brown and Sophia Harman. Global Health Reforms in Africa: Performance, Participation and Policy. Houndmills, UK: Palgrave, 2015.

The Bill and Melinda Gates Foundation. 'Who We Are' (2015). Online at: http://www.gatesfoundation.org/Who-We-Are/General-Information/FoundationFAQ (accessed 2015-11-15).

The Chronicle of Philanthropy. 'Special Report February 08, 2015: The 2015 Philanthropy 50 '. Updated March 2, 2015. Online at: https://philanthropy.com/specialreport/the2015-philanthropy-50/3 (accessed 2015-11-15).

Cohen, G. A. Rescuing Justice and Equality. Cambridge: Cambridge University Press, 2008.

Ferguson, Niall. The Great Degeneration: How Institutions Decay and Economies Die. London: Penguin Books, 2012.

Forbes. 'Bill Gates on Forbes Lists \#6: Powerful People' (2015). Online at: http://www.forbes.com/profile/bill-gates (accessed 2015-11-15).

Gates, Bill. Impatient Optimist: Bill Gates in His Own Words, edited by Lisa Rogak. Richmond, Australia: Hardie Grant Books, 2012.

Gates, Bill and Melinda Gates. 2015 Gates Annual Letter: Our Big Bet for the Future. Seattle, WA: Bill and Melinda Gates Foundation. Online at: http:/ / www.gatesnotes.com/2015-annual-letter\#0 (accessed 2016-03-1).

Gosselin, Abigail. 'Global Poverty and Responsibility: Identifying Duty-Bearers of Human Rights', Human Rights Review 8:1 (2006), pp. 35-52.

Gray, Kevin W. 'The Scope of the Global Institutional Order: Can Pogge Survive Cohen's Critique of Rawls?', De Ethica. A Journal of Philosophical, Theological and Applied Ethics 2:2 (2015), pp. 23-38.

Hahnel, Robin. Economic Justice and Democracy: From Competition to Cooperation. New York: Routledge, 2005.

Keeley, Brian. Income Inequality: The Gap between Rich and Poor. OECD Insights. Paris: OECD Publishing, 2015. Online at: http://www.oecd.org/social/income-inequality9789264246010-en.htm (accessed 2016-03-1).

Kolstad, Ivar. 'Human Rights and Assigned Duties: Implications for Corporations', Human Rights Review 10:4 (2009), pp. 569-582.

McGoey, Linsey. No Such Thing as a Free Gift: The Gates Foundation and the Price of Philanthropy. London: Verso, 2015.

Nussbaum, Martha. Creating Capabilities: The Human Development Approach. Cambridge, MA: Belknap Press of Harvard University Press, 2011.

O'Neill, Onora. Bounds of Justice. Cambridge, UK: Cambridge University Press, 2000.

Oxfam. Even It Up: Time to End Extreme Inequality. Oxford: Oxfam GB (2014). Online at: https://www.oxfam.org/sites/www.oxfam.org/files/file_attachments/cr-even-itup-extreme-inequality-291014-en.pdf (accessed 2016-02-28).

Pasquali, Valentine. 'Percentage of Public Debt in GDP around the World', Global Finance, 31 October 2015. Online at: https://www.gfmag.com/global-data/economicdata/public-debt-percentage-gdp?page $=2$ (accessed 2016-02-28).

Piketty, Thomas. Capital in the Twenty-First Century, Transl. by Arthur Goldhammer. Cambridge, MA: Belknap Press of Harvard University Press, 2014.

Pogge, Thomas. World Poverty and Human Rights: Cosmopolitan Reforms and Responsibilities. Cambridge: Polity, 2002. 
De Ethica. A Journal of Philosophical, Theological and Applied Ethics Vol. 3:1 (2016)

Päivänsalo, Ville. Balancing Reasonable Justice: John Rawls and Crucial Steps Beyond. Aldershot, UK: Ashgate, 2007.

Rawls, John. A Theory of Justice. Cambridge, MA: Belknap Press of Harvard University Press, 1971.

Sen, Amartya. The Idea of Justice. Cambridge, MA: The Belknap Press of Harvard University Press, 2009.

Singer, Peter. The Most Good You Can Do: How Effective Altruism Is Changing Ideas about Living Ethically. New Haven, CT: Yale University Press, 2015.

The World Health Organization (WHO). WHO Global Health Expenditure Atlas. Geneva: The WHO, 2012. Online at: http:/ / apps.who.int/nha/atlasfinal.pdf (accessed 2015-1115). 